\title{
Disinfection and Sterilization
}

Edited by William A. Rutala, PhD, MPH

\section{The Emerging Nosocomial Pathogens Cryptosporidium, Escherichia coli O157:H7, Helicobacter pylori, and Hepatitis C: Epidemiology, Environmental Survival, Efficacy of Disinfection, and Control Measures}

\author{
David J. Weber, MD, MPH; William A. Rutala, PhD, MPH
}

\begin{abstract}
New and emerging infectious diseases pose a threat to public health and may be responsible for nosocomial outbreaks. Cryptosporidium parvum and Escherichia coli are gastrointestinal pathogens that have caused nosocomial infections via person-toperson transmission, environmental contamination, or contaminated water or food. Helicobacter pylori has been transmitted via inadequately disinfected endoscopes. Finally, hepatitis C may be acquired by healthcare personnel by percutaneous or mucous
\end{abstract}

The 1992 report by the Institute of Medicine, "Emerging Infections: Microbial Threats to Health in the United States," called attention to the threats posed by new and emerging infectious diseases. ${ }^{1}$ The multiple reasons for the emergence of new infectious diseases or increasing incidence of previously described agents have been well described in review articles. ${ }^{2,3}$ Infection control professionals must deal with new and emerging nosocomial pathogens. The reasons for the emergence of new nosocomial pathogens include enhanced survival of immunocompromised hosts, acquisition and spread of adaptive genes (ie, antibiotic resistance and virulence genes), enhanced ability to survive in new ecologic niches, increasing use of invasive procedures, unrecognized virulence, prior under-identification due to difficulties in culturing, and increased recognition due to taxonomic clarification. ${ }^{4}$

This article will review the epidemiology, environmental survival, efficacy of disinfection and sterilization, and control measures of several emerging nosocomial membrane exposure to blood or between patients by use of contaminated blood products or via environmental contamination. Rigorous adherence to Standard Precautions, Contact Precautions for patients with infectious diarrhea, disinfection of environmental surfaces, and appropriate disinfection of endoscopes are adequate to prevent nosocomial acquisition of these pathogens (Infect Control Hosp Epidemiol 2001;22:306-315).

pathogens: Cryptosporidium parvum, Escherichia coli O157:H7, Helicobacter pylori, and hepatitis C.

\section{CRYPTOSPORIDIUM SPECIES}

Epidemiology and Nosocomial Significance

$C$ parvum, a protozoa belonging to the suborder Eimeriina, is a well-recognized cause of gastroenteritis in both immune-compromised ${ }^{5,6}$ and immune-competent persons. ${ }^{7}$ Infection is acquired via ingestion of cryptosporidial cysts and has been linked to potable water ${ }^{8}$; ingestion of contaminated food ${ }^{9,10}$; drinking unpasteurized apple juice ${ }^{11}$; recreational water activities, including swimming pools, ${ }^{8,12,13}$ lakes, ${ }^{8}$ and water parks ${ }^{14}$; close person-to-person contact $^{7}$; and contact with farm animals. ${ }^{15}$

Cryptosporidiosis represents an important emerging highly infectious pathogen for the following reasons. ${ }^{16-19}$ First, it is a common cause of self-limited gastroenteritis in the normal host and can cause potentially life-threatening disease in immunocompromised persons. Second, it is a highly infectious enteric pathogen. Based on human volun-

From the Division of Infectious Diseases, Department of Medicine, University of North Carolina (UNC) at Chapel Hill, and the UNC Health Care System, Chapel Hill, North Carolina.

Address reprint requests to David Jay Weber, MD, MHA, MPH, CB \#7030 Burnett-Womack, 547, Division of Infectious Diseases, UNC at Chapel Hill, Chapel Hill, NC, 27599-7030.

01-SX-015. Weber DJ, Rutala WA. The emerging nosocomial pathogens Cryptosporidium, Escherichia coli O157:H7, Helicobacter pylori, and hepatitis C: epidemiology, environmental survival, efficacy of disinfection, and control measures. Infect Control Hosp Epidemiol 2001;22:306-315. 
teer studies, the dose necessary to infect $50 \%$ of those exposed $\left(\mathrm{ID}_{50}\right)$ has been estimated at only 132 oocysts; some infections followed the ingestion of only 30 oocysts, ${ }^{20}$ and infections after the ingestion of a single oocyst have been reported. ${ }^{21}$ Third, it is persistent in water and resistant to chlorine at levels used in potable and swimmingpool water. ${ }^{22,23}$ Fourth, it is ubiquitous in many feral, domestic, and agricultural animals, representing a major threat to the water supply in the United States. The small dose required for infection, the fecal-oral route of transmission, and prolonged environmental survival in water allows Cryptosporidium to spread in households, healthcare facilities, and child-care centers.

Nosocomial transmission has been reported. ${ }^{24-30}$ Direct $^{24,25}$ and indirect ${ }^{26-28}$ person-to-person transmission (via contaminated hands) has been incriminated as the likely mechanism of transmission. In addition, ice contaminated by a patient has led to an outbreak among patients and staff. ${ }^{29}$ Multiple outbreaks have been reported in child-care centers. ${ }^{31-34}$ Outbreaks in veterinary facilities have involved students and staff. ${ }^{35}$

Cryptosporidium poses significant challenges to public health and water authorities. ${ }^{36}$ Large outbreaks of cryptosporidiosis associated with contaminated drinking water have occurred in Milwaukee ${ }^{37}$ and Las Vegas. ${ }^{38}$ Overall, cryptosporidiosis accounted for more than $70 \%$ of illnesses associated with drinking water outbreaks reported to the Centers for Disease Control and Prevention (CDC) between 1997 and $1998 .{ }^{8}$

\section{Environmental Survival}

C parvum is capable of surviving for long periods of time when immersed in water. First-order kinetics of die-off rates of $C$ parvum experimentally exposed to natural river water ranged from 0.013 to $0.039 \log _{10}$ per day. ${ }^{39}$ Die-off was higher in natural river water than in synthetic hard water. ${ }^{39}$

The survival of $C$ parvum on experimentally contaminated environmental surfaces has been examined. Robertson et al used a vital dye test to evaluate $C$ parvum oocyst survival on surfaces at room temperature and observed $97 \%$ loss of viability by 2 hours and $100 \%$ by 4 hours. ${ }^{40}$ Barbee and colleagues, using a viability assay, reported the following decreases in infective $C$ parvum oocysts with time: 30 minutes, $2.9-\log _{10} ; 60$ minutes, 3.8$\log _{10}$; and 90 minutes, $>4.0-\log _{10}{ }^{41}$ More prolonged survival has been reported when Cryptosporidium in a diarrheal stool is applied to an environmental surface; Anderson noted that Cryptosporidium in a diarrheal stool smeared on a wooden surface survived for up to 72 hours. $^{42}$

\section{Efficacy of Disinfection and Sterilization}

Cryptosporidium is relatively resistant to chlorine at concentrations used in potable water. $C$ parvum is not completely inactivated by most disinfectants used in health care, including ethyl alcohol, ${ }^{41}$ glutaraldehyde, ${ }^{41,43} 5.25 \%$ hypochlorite, ${ }^{41}$ peracetic acid, ${ }^{41}$ ortho-phthalaldehyde, ${ }^{41}$ phenol, ${ }^{41,43}$ povidone-iodine, ${ }^{41-43}$ and quaternary ammoni-
TABLE 1

EFFiCACy of Disinfection Methods Against CRrptosporidium PARVUM

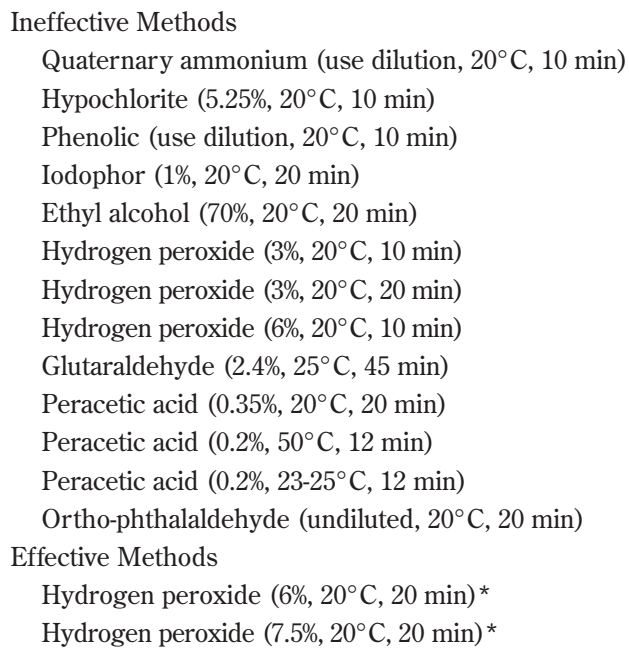

${ }^{*}>3-\log$ kill.

um compounds ${ }^{41}$ (Table 1). The only chemical disinfectants or sterilants able to inactivate greater than $3 \log _{10}$ of $C$ parvum were $6 \%$ and $7 \%$ hydrogen peroxide. ${ }^{41}$ Sterilization methods that will fully inactivate $C$ parvum include steam, ${ }^{41}$ ethylene oxide, ${ }^{41,44}$ and the Sterrad $100 .{ }^{41}$

\section{Control Measures}

The major threat posed by Cryptosporidium in the hospital is the acquisition of infection by immunocompromised patients via ingestion of contaminated potable water. The CDC has recommended that human immunodeficiency virus (HIV)-infected persons who wish to take independent action to reduce risk for waterborne cryptosporidiosis may choose to take precautions similar to those recommended during outbreaks (ie, ingest water that has been boiled for 1 minute or filtered through a submicron filter). ${ }^{45}$ Recently the CDC recommended that hematopoietic stem cell transplant (HSCT) recipients should avoid the following activities to prevent exposure to Cryptosporidium: walking, wading, swimming, or playing in recreational water likely to be contaminated with Cryptosporidium, sewage, or animal or human wastes; ingesting water taken directly from rivers and lakes; and use of water from private wells or public wells in communities with limited populations. ${ }^{46}$ To eliminate the risk of Cryptosporidium from tap water completely, HSCT recipients can either boil or filter the water. Similar recommendations have been published in England. ${ }^{47}$ It would be prudent for hospitals to provide all immunocompromised persons (eg, due to chemotherapy or being IgA deficient or HIV-infected) with sterile water and ice for ingestion.

Patients with cryptosporidiosis can be managed using Standard Precautions. ${ }^{48}$ This CDC recommendation recently was validated by a retrospective cohort study of 37 
TABLE 2

EFFicacy of Disinfection Methods Against EsCHERICHIA COLI O157:H7

\section{Effective Methods}

Quaternary ammonium (use dilution, $20^{\circ} \mathrm{C}, 0.5 \mathrm{~min}$ )*

Hypochlorite $\left(0.525 \%, 20^{\circ} \mathrm{C}, 0.5 \mathrm{~min}\right)^{*}$

Phenolic (use dilution, $20^{\circ} \mathrm{C}, 0.5 \mathrm{~min}$ )*

Ethyl alcohol $\left(70 \%, 20^{\circ} \mathrm{C}, 0.5 \mathrm{~min}\right)^{*}$

* $>$ - $\log$ kill.

hospitalized patients, which failed to identify roommate-toroommate transmission of Cryptosporidium. ${ }^{49}$ Contact Precautions should be used for diapered or incontinent children less than 6 years of age for the duration of the illness. HIV-infected patients, especially those who are severely immunocompromised, should not share a room with persons infected with Cryptosporidium. ${ }^{45}$

Current hospital cleaning practices appear satisfactory to prevent nosocomial transmission. Chest-type ice machines should not be used in clinical areas of the hospital to prevent possible contamination. ${ }^{29}$ Endoscopes are unlikely to represent an important vehicle for the crosstransmission of $C$ parvum, because mechanical cleaning will remove approximately $10^{4}$ organisms, and rapid drying results in loss of $C$ parvum viability. ${ }^{41}$

\section{ESCHERICHIA COLI O157:H7 \\ Epidemiology and Nosocomial Significance}

There has been growing appreciation of the major public health impact of foodborne diseases ${ }^{50-53}$ and the importance of $E$ coli $\mathrm{O} 157: \mathrm{H} 7$ as a foodborne pathogen. ${ }^{54,55} E$ coli $0157: \mathrm{H} 7$ was first recognized as a human pathogen in 1982, when two outbreaks in the United States were associated with eating undercooked hamburgers. ${ }^{56,57}$ Currently, $E$ coli $\mathrm{O} 157: \mathrm{H} 7$ is estimated to result annually in 20,000 cases of gastroenteritis and 100 to 200 deaths. ${ }^{51} \mathrm{E}$ coli $\mathrm{0} 157: \mathrm{H} 7$ is transmitted from its bovine reservoir to humans via direct contact or via contaminated water or food. ${ }^{58}$ Raw or undercooked meat has been the food item most commonly associated with outbreaks of $E$ coli O157:H7, but infection has followed ingestion of other contaminated foods, including vegetables such as lettuce and radish sprouts; unpasteurized juice, milk, or cheese; and water. ${ }^{59,60}$ Secondary person-toperson transmission may occur following initial human infection; the household transmission rate has been calculated to be $4 \%$ to $15 \% .{ }^{61}$ Person-to-person transmission is facilitated by the low inoculum dose required for infection. In two outbreak investigations, the infectious dose of E coli $0157:$ H7 was found to be fewer than 700 organisms $^{62}$ and fewer than 50 organisms. ${ }^{63}$

Nosocomial outbreaks of $E$ coli $0157:$ H7 have been reported occasionally. ${ }^{64-68}$ Evaluations of these outbreaks have suggested direct person-to-person transmission, ${ }^{65-68}$ indirect transmission via environmental contamination, ${ }^{68}$ and contaminated food (lettuce). ${ }^{66}$ Transmission from patients to staff has been reported, but the number of staff infected in such incidents usually is low. ${ }^{67,68}$ Outbreaks also have been reported in child-care centers ${ }^{69-71}$ and extendedcare facilities. ${ }^{72,73}$ In some reported outbreaks, it has not been possible to establish if staff have acquired infection from eating the same implicated food or secondarily from patients. ${ }^{66-73}$

\section{Environmental Survival}

E coli $\mathrm{O} 157: \mathrm{H} 7$ is capable of surviving for prolonged periods of time in soil, meats, and produce. For example, E coli 0157:H7 was capable of surviving for up to 144 hours in untreated milk held at $7^{\circ} \mathrm{C}$ without a change in colony counts, but when held at $15^{\circ} \mathrm{C}$ a $3.7-\log _{10}$ increase was noted. ${ }^{74}$ When inoculated into chicken manure, $E$ coli O157:H7 demonstrated a 1- to $2-\log _{10}$ increase over a period of 2 days at $20^{\circ} \mathrm{C} .{ }^{75}$ Drying of the manure to $10 \%$ moisture at $20^{\circ} \mathrm{C}$ resulted in $1-$ to $2-\log _{10}$ decrease in counts over 24 hours. When inoculated onto lettuce, $E$ coli O157:H7 was demonstrated to survive at $4^{\circ} \mathrm{C}$ for up to 15 days. $^{76}$

\section{Efficacy of Disinfection and Sterilization}

Disinfectants, including chlorine compounds, are unable to eliminate $E$ coli O157:H7 experimentally inoculated onto alfalfa seeds or sprouts ${ }^{77,78}$ or beef-carcass surfaces. ${ }^{79}$ However, chlorine at approximately $1 \mathrm{ppm}$ has been found capable of eliminating approximately $4 \log _{10}$ of $E$ coli $\mathrm{O} 157: \mathrm{H} 7$ within 1 minute in a suspension test. ${ }^{80}$

Electrolyzed oxidizing water at $23^{\circ} \mathrm{C}$ was effective in 10 minutes in producing a $5-\log _{10}$ decrease in $E$ coli O157:H7 inoculated onto kitchen cutting boards. ${ }^{81}$ The following disinfectants were effective in eliminating $>5$ $\log _{10}$ of $E$ coli O157:H7 within 30 seconds: a quaternary ammonium compound, a phenolic, a hypochlorite (1:10 dilution of $5.25 \%$ bleach), and ethanol ${ }^{82}$ (Table 2).

\section{Control Measures}

E coli represents an important public health threat. Consumers are advised to follow food-safety guidelines. ${ }^{83}$ These include thorough heating of potentially hazardous foods and prompt refrigeration of used foods. Additional measures include separating cooked and raw foods and preventing contamination of cooked foods by drippings from raw foods. Contaminated surfaces (eg, cutting boards) should be washed. Consumers should consider avoiding high-risk foods such as raw or runny eggs and undercooked hamburger meat (ie, pink or red in center). Raw sprouts should not be consumed by the elderly, children, and those with a compromised immune system. ${ }^{84}$

Patients infected with $E$ coli $0157:$ H7 can be managed using Standard Precautions. ${ }^{48}$ Contact Precautions should be used for diapered or incontinent children less than 6 years of age for the duration of the illness. Standard hospital surface disinfectants are adequate for inactivating $E$ coli $\mathrm{O} 157: \mathrm{H} 7$ and can be used for terminal cleaning or cleaning of contaminated surfaces. Current 
guidelines for the disinfection of endoscopes should be followed.

\section{HELICOBACTER PYLORI}

\section{Epidemiology and Nosocomial Significance}

$H$ pylori is a fastidious, microaerophilic, spiralshaped, gram-negative rod. First isolated in $1983,{ }^{85,86} \mathrm{H}$ pylori is now known to play an important role in the development of gastritis, peptic ulcer disease, distal gastric adenocarcinoma, and gastric lymphoma. ${ }^{87-89}$ The incidence of $H$ pylori infection in developed countries has been estimated to be approximately $0.5 \%$, with the incidence decreasing over time. ${ }^{90}$

The route of $H$ pylori transmission remains a topic of intense controversy because of incomplete information, including how the organism leaves its host and enters the environment, where (if anywhere) the organism persists in the environment, how people become infected, and whether all persons are susceptible to infection. ${ }^{88,91}$ Circumstantial evidence suggests that the most likely means of $H$ pylori transmission is direct person-toperson spread. This may occur via fecal-oral, oral-oral, or gastric-oral routes. Fecal-oral transmission is suggested by the finding of higher prevalence rates of infection in crowded households, institutions for the disabled, or households with young children. ${ }^{88}$ Fecal-oral transmission is supported by the occasional isolation of $H$ pylori from the stools of adults ${ }^{92,93}$ and children. ${ }^{92}$ Oral-oral transmission is suggested by the ability to detect $H$ pylori DNA by polymerase chain reaction (PCR) from both saliva and dental plaque, although viable $H$ pylori have only occasionally been isolated from the mouth. ${ }^{94}$ Gastric-oral transmission has been suggested by iatrogenic transmission of $H$ pylori in endoscopy suites (see below). Epidemiological studies of Peruvian children have shown that $H$ pylori infection is associated with consuming food from street vendors ${ }^{95}$ and drinking potable water from community wells, ${ }^{96}$ thus suggesting transmission via contaminated food and water.

Nosocomial transmission of $H$ pylori via inadequately cleaned and disinfected medical equipment, most commonly endoscopes, has been suggested by epidemiological investigations and demonstrated by molecular techniques. ${ }^{97} \mathrm{H}$ pylori has been isolated from used endoscopes and biopsy forceps. ${ }^{98}$ Epidemic gastritis with hypochlorhydria, a syndrome compatible with $H$ pylori infection, has been reported following the use on multiple patients of $\mathrm{pH}$ electrodes that were not disinfected between patients. ${ }^{99,100}$ Epidemiological investigations have suggested cross-transmission of $H$ pylori by potentially contaminated endoscopes. ${ }^{101-103}$ Patient-to-patient transmission of $H$ pylori via contaminated endoscopes has been proven by use of molecular techniques ${ }^{104,105}$; all cases of transmission have followed the use of ineffective disinfectants such as $70 \%$ ethano $1^{103,104}$ or $0.2 \%$ benzethonium chloride. ${ }^{101}$

Mouth-to-mouth transmission has been reported to lead to acquisition of $H$ pylori. ${ }^{106}$ A sero-epidemiological study demonstrated that endoscopy personnel had a higher prevalence of $H$ pylori than blood donors, raising the potential that $H$ pylori was an occupational hazard. ${ }^{107}$ However, the use of a highly screened population (ie, blood donors) as a control group may have been inappropriate. Further, seropositivity was not associated with years involved in endoscopy or number of endoscopies performed monthly.

\section{Environmental Survival}

Data on the environmental survival of $H$ pylori is limited. $H$ pylori can change from its normal rod-like appearance into a range of coccoidal forms, especially after antibiotic treatment or in vitro after prolonged culture. In the coccoidal form, $H$ pylori cannot be grown in culture, and thus it is believed that the hypothesis that $H$ pylori is a zoonosis or transmitted as coccoid forms by vectors (pets, houseflies) is not supported by recent research. ${ }^{108}$ It also is unknown whether the coccoidal forms can revert to the spiral, multiplying forms. However, Cellini and colleagues demonstrated in a rodent model that administration of the coccoid form of $H$ pylori resulted in infection. ${ }^{109}$ The viability of the coccoidal forms represents an important scientific question bearing on the potential infectivity of contaminated water and food, and the role of the environment in transmission of $H$ pylori.

In an early experiment, the median survival of $H$ pylori in distilled water or saline was found to be only 0 to 2 days. ${ }^{110}$ Using a higher titer of $H$ pylori, Shahamat demonstrated that $H$ pylori could survive for 48 hours in sterile river water at $4^{\circ} \mathrm{C}$; in some cases, viable bacteria were culturable for up to 20 to 30 days, depending on physical conditions of the environment. ${ }^{111} \mathrm{H}$ pylori is capable of surviving for up to 10 days in milk at $4^{\circ} \mathrm{C}$ and 4 days in tap water, with a steady decrease in colony-forming units; the nonculturable coccoid form was present at 7 days in tap water kept at $4^{\circ} \mathrm{C} .{ }^{112} \mathrm{H}$ pylori DNA has been detected by PCR in $12 \%$ to $36 \%$ of potable-water sites (private wells, municipal tap water, wastewater) tested in Sweden ${ }^{113}$ and in samples of tap water, well water, and field soil in Japan. ${ }^{114}$

The survival of $H$ pylori on environmental surfaces has not been determined.

\section{Efficacy of Disinfection and Sterilization}

Only limited data are available on the susceptibility of $H$ pylori to disinfectants (Table 3 ). Using a suspension

TABLE 3

EFFicacy of Disinfection Methods Against HeLICOBACTER PYLORI

\section{Effective Methods}

Hypochlorite $\left(150 \mathrm{ppm}, 25^{\circ} \mathrm{C}, \leqslant 0.5 \mathrm{~min}\right)$ *

Ethyl alcohol $\left(80 \%, 25^{\circ} \mathrm{C}, 0.25 \mathrm{~min}\right)$ *

Glutaraldehyde $\left(0.5 \%, 25^{\circ} \mathrm{C}, 0.25 \mathrm{~min}\right)$ *

* >7-log kill. 
test, Akamatsu and colleagues assessed the effectiveness of a variety of disinfectants against nine strains of $H$ pylori. ${ }^{115}$ Ethanol (80\%) and glutaraldehyde (0.5\%) killed all strains within 15 seconds, whereas chlorhexidine gluconate $(0.05 \%$ and $1.0 \%)$, benzalkonium chloride $(0.025 \%$ and $0.1 \%$, alkyldiaminoethylglycine hydrochloride $(0.1 \%)$, povidone-iodine $(0.1 \%)$, and sodium hypochlorite (150 ppm) killed all strains within 30 seconds. Both ethanol (80\%) and glutaraldehyde (0.5\%) retained similar bactericidal activity in the presence of organic matter, whereas the other disinfectants showed reduced bactericidal activity. In particular, the bactericidal activities of povidone-iodine $(0.1 \%)$ and sodium hypochlorite (150 $\mathrm{ppm}$ ) were markedly decreased in the presence of dried yeast solution, with killing times increased to 5 to $10 \mathrm{~min}$ utes and 5 to 30 minutes, respectively.

Immersion of biopsy forceps in formalin prior to obtaining a specimen does not affect the ability to obtain a culture of $H$ pylori from the biopsy specimen. ${ }^{116}$ The following methods have been demonstrated to be ineffective for eliminating $H$ pylori from endoscopes: cleaning with soap and water, ${ }^{117,118}$ immersion in $70 \%$ ethanol for 3 minutes, ${ }^{104}$ instillation of $70 \%$ ethanol, ${ }^{103}$ instillation of 30 $\mathrm{mL}$ of $83 \%$ methanol, ${ }^{117}$ and $0.2 \%$ benzethonium chloride solution. ${ }^{101}$ The differing results with regard to the efficacy of ethyl alcohol are unexplained. Cleaning followed by use of $2 \%$ alkaline glutaraldehyde has been demonstrated by culture to be effective in eliminating $H$ pylori. ${ }^{117-119}$ Epidemiological investigations of patients who had undergone endoscopy with scopes mechanically washed and disinfected with $2.0 \%$ to $2.3 \%$ glutaraldehyde have revealed no evidence of cross-transmission of $H$ pylori. ${ }^{103-120}$ Disinfection of experimentally contaminated endoscopes using $2 \%$ glutaraldehyde (10-m, 20-m, and 45$\mathrm{m}$ exposure times) or the Steris (Steris Corp, Menton, $\mathrm{OH}$ ) system (with and without active peracetic acid) has been demonstrated to be effective in eliminating $H$ pylori. ${ }^{118} H$ pylori DNA has been detected by PCR in fluid flushed from endoscope channels following cleaning and disinfection with $2 \%$ glutaraldehyde. ${ }^{121}$ The clinical significance of this finding is unclear.

In vitro experiments have demonstrated a $>3.5-\log _{10}$ reduction in $H$ pylori after exposure to $0.5 \mathrm{mg} / \mathrm{L}$ of free chlorine for 80 seconds. ${ }^{122}$

\section{Control Measures}

$H$ pylori represents an important nosocomial pathogen that commonly contaminates endoscopes and has been transmitted by inadequately cleaned and disinfected scopes. However, cleaning followed by disinfection of endoscopes with $\geqslant 2.0 \%$ glutaraldehyde or peracetic acid has been demonstrated to be effective in eliminating $H$ pylori. Standard chlorination of potable water appears adequate to eliminate the possibility of transmission via contaminated water. Studies demonstrating an increased risk of $H$ pylori among endoscopic personnel are flawed, and additional studies should be undertaken before concluding that such personnel are at increased risk for acquisition of $H$ pylori. However, personnel should use Standard Precautions when performing endoscopy.

Although data are lacking regarding the possibility of person-to-person transmission when close contact occurs, the possibility of transmission cannot be ruled out in settings such as child-care centers and institutions caring for mentally disabled children.

\section{HEPATITIS C \\ Epidemiology and Nosocomial Significance}

Hepatitis C (HCV), an RNA virus, is the most common chronic bloodborne infection in the United States. The annual number of new infections in 1996 was 36,000, which represents a decline of more than $80 \%$ since 1989.123 Data from the Third National Health and Nutrition Examination Survey, conducted from 1988 through 1994, indicated that an estimated $1.8 \%$ of US residents have been infected with $\mathrm{HCV} .{ }^{124}$ The estimated prevalence in selected population groups is as follows ${ }^{123,125}$ : persons with hemophilia treated with product made before 1987, 87\%; current injecting drug users, 79\%; chronic hemodialysis patients, $10 \%$; persons reporting a history of sexually transmitted diseases, $6 \%$; infants born to infected mothers, $5 \%$; men who have sex with other men, $4 \%$; and volunteer blood donors, $0.16 \%$. Populationbased studies indicate that $40 \%$ of chronic liver disease is HCV-related, resulting in an estimated 8,000-10,000 deaths per year. ${ }^{123}$

$\mathrm{HCV}$ is transmitted primarily through large or repeated direct percutaneous exposures to blood. The majority of patients infected with HCV in the United States and Europe acquired the disease through transfusion or injecting drug use. Prior to the discovery of HCV in 1989 and the subsequent implementation of an HCV-antibody detection assay for screening of blood donors in 1990, the risk of acquiring HCV through blood transfusion was as high as 1 in 200 units. ${ }^{126}$ Following the introduction of improved HCV antibody assays in 1992 and 1996, the risk fell to 1 per 103,000 units of blood. ${ }^{127}$ With the introduction of nucleic acid testing in the spring of 1999, it is estimated that the risk of transfusion-transmitted $\mathrm{HCV}$ will fall to between 1 in 500,000 and 1 in 1,000,000 units. ${ }^{126} \mathrm{HCV}$ transmission also was associated with use of tainted clottingfactor concentrates in hemophiliacs, ${ }^{128}$ contaminated immunoglobulin preparations used to treat patients with humoral defects, ${ }^{129-131}$ contaminated anti-rhesus D preparations used in young women, ${ }^{132,133}$ and plasmapheresis. ${ }^{134,135}$ Transmission of HCV by infected donor tissue has been demonstrated in kidney, heart, and liver transplantation. ${ }^{136}$ In the United States, no association has been found between hepatitis $\mathrm{C}$ infection and exposures resulting from medical, surgical, or dental procedures; tattooing, acupuncture, or ear piercing; or foreign travel. ${ }^{125}$

Between 1983/84 and 1995/96, injecting drug use became an increasingly important mechanism of $\mathrm{HCV}$ acquisition, accounting for more than $50 \%$ of HCV transmission in the United States. However, in parallel with the overall decrease in $\mathrm{HCV}$ prevalence, the number of 
cases of acute HCV among injecting drug users has declined dramatically since 1989. Currently, injecting drug use accounts for $60 \%$ of HCV transmission, sexual contact for $20 \%$, and other known exposures (household, perinatal, occupational) for $10 \% .{ }^{125}$ In the remaining $10 \%$, no recognized source of infection can be identified, although most persons in the category are associated with low socioeconomic level.

Nosocomial transmission of $\mathrm{HCV}$ has been reviewed. ${ }^{123,137-140}$ The most important nosocomial source was transfusions of blood products, until the development and implementation of improved screening methods. Hemodialysis patients are at high risk for acquisition of hepatitis $\mathrm{C}$. The prevalence of anti-HCV among dialysis patients ranges from $8 \%$ to $36 \%$ in the United States ${ }^{141}$ and from $1 \%$ to $47 \%$ worldwide. ${ }^{142,143}$ A survey of 2,647 US hemodialysis centers in 1995 by the CDC revealed that the prevalence of anti-HCV was $10.4 \%$ among patients. ${ }^{144} \mathrm{~A}$ similar survey of 3,077 centers in 1997 revealed that the prevalence of anti-HCV was $9.3 \%$ among the $48 \%$ of centers that tested patients for anti-HCV. ${ }^{145}$ Patient-to-patient transmission in hemodialysis centers has been confirmed by molecular analysis of HCV strains isolated. ${ }^{146-152}$ Studies have consistently demonstrated an association between anti-HCV positivity and increasing years on dialysis, an association that is independent of blood transfusions. ${ }^{140}$ Investigation of dialysis-associated outbreaks of hepatitis $\mathrm{C}$ indicates that $\mathrm{HCV}$ transmission might occur among patients in a hemodialysis center because of incorrect implementation of infection control practices, especially sharing medication vials and supplies. ${ }^{123} \mathrm{HCV}$ has been detected by PCR on the hands of healthcare personnel caring for hemodialysis patients, despite the use of Standard Precautions. ${ }^{153}$

Nosocomial transmission of HCV has only occasionally been reported in healthcare settings other than hemodialysis. HCV has been transmitted at least twice during colonoscopy. ${ }^{154,155}$ The former case was likely due to inadequate cleaning and disinfection of the colonoscope, whereas the latter case was likely due to use of a multidose anesthetic vial or a shared syringe. In addition, HCV has been transmitted during endoscopic retrograde cholangiography. ${ }^{156}$ An outbreak on a pediatric oncology ward was felt to be due to contamination of multidose vials. ${ }^{157}$ An investigation of institutionalized psychiatric patients revealed a higher-than-expected prevalence of anti-HCV. ${ }^{158}$ A case-control study demonstrated the following independent risk factors for infection: duration of hospitalization, age, razor sharing, and history of surgery. On this basis, the authors suggested that razor sharing be avoided. ${ }^{158}$ An outbreak of hepatitis $\mathrm{C}$ infection confirmed by molecular typing was reported in a fertility clinic during procedures for assisted conception. ${ }^{159}$ Despite an extensive investigation, the exact means of cross-transmission was not discovered, and the most likely route of contamination was healthcare workers. Schvarcz and colleagues ${ }^{160}$ investigated a cluster of hepatitis $\mathrm{C}$ confirmed by phylogenetic analysis among subjects participating in a research project; cross- transmission was felt to result from the failure to adhere strictly to Standard Precautions. Cross-transmission due to contamination of anesthetic circuitry was suggested as the cause of an outbreak of hepatitis $\mathrm{C}$ among patients who had undergone surgery in the same operating suite on the same day. ${ }^{161}$ This outbreak led to changes in local guidelines for infection control in anesthesiology ${ }^{162}$ and generated significant controversy about the potential mode of cross-transmission, ${ }^{163,164}$ as well as the need to revise current US infection control guidelines in anesthesiology. ${ }^{163.164}$ Lloyd and coworkers subsequently demonstrated that a hydrophobic pleated-membrane breathing circuit filter consistently prevented the passage of hepatitis $\mathrm{C}$ virus, whereas a large-pore "electret" filter design was ineffective. ${ }^{165}$

Healthcare workers who frequently have contact with blood are at risk of occupationally acquired infection with bloodborne pathogens. However, the prevalence of $\mathrm{HCV}$ infection among healthcare workers is approximately $1 \%$ to $2 \%{ }^{145,166-170}$ This rate, which includes orthopedic, general, and oral surgeons, and hemodialysis staff, is similar to the rate in the general population. Following a percutaneous injury with a contaminated sharp or a needlestick, the rate of seroconversion among healthcare workers has averaged $1.8 \%$ (range, $0 \%$ to $7 \%$ ). ${ }^{123}$ One study from Japan, which used reverse transcriptase PCR to detect $\mathrm{HCV}$ RNA, reported a seroconversion rate of $10 \%$ following contaminated needlestick injuries. ${ }^{171}$ Transmission of HCV has followed from blood splashed to conjunctivae. ${ }^{172,173}$ No case reports have described $\mathrm{HCV}$ transmission following blood exposure of nonintact skin.

Physician-to-patient transmission of HCV has rarely been reported, but three papers reported transmission during surgery. ${ }^{174-176}$ In two reports only a single patient was infected, but in one report five patients were infected ${ }^{175}$; molecular typing suggested transmission from the healthcare worker. ${ }^{175,176}$

\section{Environmental Survival}

The environmental survival of $\mathrm{HCV}$ is unknown. No studies have been conducted for HCV comparable to that conducted by Favero and Bond, ${ }^{177}$ which demonstrated that hepatitis B virus remains infectious for at least 1 week on environmental surfaces. As measured by PCR, there is a rapid decline in detectable HCV RNA of 3 to $4 \log _{10}$ within 14 days when HCV-contaminated whole blood and serum were stored at room temperature. ${ }^{178}$

\section{Efficacy of Disinfection and Sterilization}

Using experimentally contaminated hysteroscopes, Sartor and colleagues detected HCV by PCR in 1 (3\%) of 34 samples following cleaning with a detergent, but in no samples following treatment with a $2 \%$ glutaraldehyde solution for 20 minutes. ${ }^{179}$ Rey and colleagues demonstrated complete elimination of hepatitis $C$ virus by PCR from endoscopes used on chronically infected patients following cleaning and disinfection for 3 to 5 minutes in glutaraldehyde. ${ }^{180}$ Similarly, Chanzy and coworkers used 
PCR to demonstrate complete elimination of HCV following standard disinfection by experimentally contaminated endoscopes. ${ }^{181}$

\section{Control Measures}

Transfusions now represent only a minimal risk for the transmission of $\mathrm{HCV}$ in healthcare facilities. Nosocomial transmission of $\mathrm{HCV}$ is possible if infection control techniques or disinfection procedures are inadequate and contaminated equipment is shared among patients. ${ }^{123}$ Fortunately, cases of nosocomial transmission have been reported only rarely from the United States. Standard methods of cleaning and disinfection appear adequate to prevent transmission of $\mathrm{HCV}$ via contaminated endoscopes. ${ }^{182}$ Additional studies to assess the mechanisms of HCV transmission in hemodialysis centers are needed. In addition, strategies to prevent transmission in hemodialysis centers need to be validated.

$\mathrm{HCV}$ acquisition via percutaneous injury is an important hazard for medical personnel. The lack of proven effective pre- or postexposure prophylaxis, the current prevalence of chronic HCV infection in the general (approximately 2\%) and patient populations, and the rate of seroconversion following percutaneous injuries (1.8\%) mean that $\mathrm{HCV}$ infection represents the most important bloodborne-transmitted disease threat to healthcare personnel. Efforts at prevention of HCV transmission to healthcare workers should focus on general measures to reduce the incidence of needlestick injuries.

\section{REFERENCES}

1. Institute of Medicine. Emerging Infections: Microbial Threats to Health in the United States. Washington, DC: National Academy of Sciences; 1992.

2. Morse SS. Factors in the emergence of infectious diseases. Emerg Infect Dis 1995;1:7-15.

3. Wilson ME. Travel and the emergence of infectious diseases. Emerg Infect Dis 1995;1:39-46.

4. Mayer KH, Opal SM. Unusual nosocomial pathogens. Infect Dis Clin North Am 1989;3:883-889.

5. Connolly GM, Dryden MS, Shanson DC, Gazzard BG. Cryptosporidial diarrhoea in AIDS and its treatment. Gut 1988;29:593-597.

6. Gentile G, Venditti M, Micozzi A, Caprioli A, Donelli G, Tirindelli C, et al. Cryptosporidiosis in patients with hematologic malignancies. Rev Infect Dis 1991;13:842-846.

7. Wolfson JS, Richter JM, Waldron MA, Weber DJ, McCarthy DM, Hopkins CC. Cryptosporidiosis in immunocompetent patients. $N$ Engl J Med 1985;312:1278-1282.

8. Barwick RS, Levy DA, Craun GF, Beach MJ, Calderon RL. Surveillance for waterborne-disease outbreaks-United States, 1997-1998. Mor Mortal Wkly Rep CDC Surveill Summ 2000 May 26, 2000;49:1-21.

9. Centers for Disease Control and Prevention. Foodborne outbreak of diarrheal illness associated with Cryptosporidium parvum-Minnesota, 1995. MMWR 1996;45:783-784.

10. Quiroz ES, Bern C, MacArthur JR, Xiao L, Fletcher M, Arrowood MJ, et al. An outbreak of cryptosporidiosis linked to a foodhandler. J Infect Dis 2000;181:695-700

11. Centers for Disease Control and Prevention. Outbreaks of Escherichia coli O157:H7 infection and cryptosporidiosis associated with drinking unpasteurized apple cider-Connecticut and New York, October 1996. MMWR 1997;46:4-8.

12. Sorvillo FJ, Fujioka K, Nahlen B, Torney MP, Kebabjian RS, Mascola L. Swimming-associated cryptosporidiosis. Am J Public Health 1992;82:742-744.

13. MacKenzie WR, Kazmierczak JJ, Davis JP. An outbreak of cryptosporidiosis associated with a resort swimming pool. Epidemiol Infect 1995; $115: 545-553$.

14. Centers for Disease Control and Prevention. Outbreak of gastroenteritis associated with an interactive water fountain at a beachside parkFlorida, 1999. MMWR 2000;49:565-568.
15. Reif JS, Wimmer L, Smith JA, Dargatz DA, Cheney JM. Human cryptosporidiosis associated with an epizootic in calves. Am J Public Health 1989;79:1528-1530

16. Current WL, Garcia LS. Cryptosporidiosis. Clin Microbiol Rev 1991;4:325-358.

17, Guerrant RL. Cryptosporidiosis: an emerging, highly infectious threat. Emerg Infect Dis 1997;3:51-55.

18. Addiss DG, Juranek DD, Schwartz DA. Cryptosporidiosis. In: Horsburgh CR Jr, Nelson AM, eds. Pathology of Emerging Infections. Washington, DC: ASM Press; 1997:243-256.

19. Guerrant RL, Thielman NM. Emerging enteric protozoa: Cryptosporidium, Cyclospora, and Microsporidia. In: Scheld WM, Armstrong D, Hughes JM, eds. Emerging Infections I. Washington DC: ASM Press; 1998:233-245.

20. DuPont HL, Chappell CL, Sterling CR, Okhuysen PC, Rose JB, Jakubowski W. The infectivity of Cryptosporidium parvum in healthy volunteers. N Engl J Med 1995;332:855-859.

21. Hass CN, Rose JB. Reconciliation of microbial risk models and outbreak epidemiology: the case of the Milwaukee outbreak. Proceedings of the American Water Works Association 1994;517-523.

22. Rose JB. Environmental ecology of Cryptosporidium and public health implications. Annu Rev Public Health 1997;18:135-161.

23. Laberge I, Griffiths MW, Griffiths MW. Prevalence, detection and control of Cryptosporidium parvum in food. Int J Food Microbiol 1996;32:126.

24. Baxby D, Hart CA, Taylor C. Human cryptosporidiosis: a possible case of hospital cross infection. BMJ 1983;287:1760-1761.

25. Koch KL, Phillips DJ, Aber RC, Current WL. Cryptosporidiosis in hospital personnel: evidence for person-to-person transmission. Ann Intern Med 1985;102:593-596.

26. Martino P, Gentile G, Caprioli A, Baldassarri L, Donelli G, Arcese W, et al. Hospital-acquired cryptosporidiosis in a bone marrow transplantation unit. J Infect Dis 1988;158:647-648.

27. Sarabia-Arce S, Salazar-Lindo E, Gilman RH, Naranjo J, Miranda E. Casecontrol study of Cryptosporidium parvum infection in Peruvian children hospitalized for diarrhea: possible association with malnutrition and nosocomial infection. Pediatr Infect Dis J 1990;9:627-631.

28. Navarrete S, Stetler HC, Avila C, Garcia Aranda, JA, Santos-Preciado JI. An outbreak of Cryptosporidium diarrhea in a pediatric hospital. Pediatr Infect Dis J 1991;10:248-250.

29. Ravn P, Lundgren JD, Kjaeldgaard P, Holten-Anderson W, Hojlyng N, Nielsen JO, et al. Nosocomial outbreak of cryptosporidiosis in AIDS patients. BMJ 1991;302:277-280.

30. Arikan S, Erguven S, Akyon Y, Gunalp A. Cryptosporidiosis in immunocompromised patients in a Turkish university hospital. Acta Microbiol Immunol Hung 1999;46:33-40.

31. Centers for Disease Control. Cryptosporidiosis among children attending day-care centers-Georgia, Pennsylvania, Michigan, California, New Mexico. MMWR 1984;33:599-601.

32. Alpert G, Bell LM, Kirkpatrick CE, Budnick LD, Campos JM, Friedman HM, et al. Outbreak of cryptosporidiosis in a day-care center. Pediatr 1986;77:152-157.

33. Heijbel H, Slaine K, Seigel B, Wall P, McNabb SJ, Gibbons W, et al. Outbreak of diarrhea in a day care center with spread to household members: the role of Cryptosporidium. Pediatr Infect Dis J 1987;6:532-535.

34. Tangermann RH, Gordon S, Wiesner P, Kreckman L. An outbreak of cryptosporidiosis in a day-care center in Georgia. Am J Epidemiol 1991;133:471-476.

35. Konkle DM, Nelson KM, Lunn DP. Nosocomial transmission of Cryptosporidium in a veterinary hospital. J Vet Intern Med 1997;11:340343.

36. Gostin LO, Lazzarini Z, Neslund VS, Osterholm MT. Water quality laws and waterborne diseases: Cryptosporidium and other emerging pathogens. Am J Public Health 2000;90:847-853.

37. MacKenzie WR, Hoxie NJ, Proctor ME, Gradus MS, Blair KA, Peterson DE, et al. A massive outbreak in Milwaukee of Cryptosporidium infection transmitted through the public water supply. N Engl J Med 1994;331:161167.

38. Goldstein ST, Juranek DD, Ravenholt O, Hightower AW, Martin DG, Mesnik JL, et al. Cryptosporidiosis: an outbreak associated with drinking water despite state-of-the-art water treatment. Ann Intern Med 1996;124:459-468.

39. Chauret C, Nolan K, Chen P, Springthorpe S, Sattar S. Aging of Cryptosporidium parvum oocysts in river water and their susceptibility to disinfection by chlorine and monochloramine. Can J Microbiol 1998;44:1154-1160.

40. Robertson LJ, Campbell AT, Smith HV. Survival of Cryptosporidium parvum oocysts under various environmental pressures. Appl Environ Microbiol 1992;58:3494-3500.

41. Barbee SL, Weber DJ, Sobsey MD, Rutala WA. Inactivation of 
Cryptosporidium parvum oocyst infectivity by disinfection and sterilization processes. Gastrointest Endosc 1999;49:605-611.

42. Anderson BC. Effect of drying on the infectivity of cryptosporidia-laden calf feces for 3- to-7-day-old mice. Am J Vet Res 1986;47:2272-2273.

43. Wilson JA, Margolin AB. The efficacy of three common hospital liquid germicides to inactivate Cryptosporidium parvum oocysts. J Hosp Infect 1999;42:231-237.

44. Fayer R, Graczyk TK, Cranfield MR, Trout JM. Gaseous disinfection of Cryptosporidium parvum oocysts. Appl Environ Microbiol 1996;62:39083909

45. Centers for Disease Control and Prevention. 1999 USPHS/IDSA guidelines for the prevention of opportunistic infections in persons infected with human immunodeficiency virus. $M M W R$ 1999;48(RR-10):1-59.

46. Centers for Disease Control and Prevention. Guidelines for preventing opportunistic infections among hematopoietic stem cell transplant recipients: recommendations of the $\mathrm{CDC}$, the Infectious Disease Society of America, and the American Society of Blood and Marrow Transplantation. MMWR 2000;49(RR-10):1-128.

47. Bouchier I. Cryptosporidiosis in water supplies. Third report of the group of experts to: Department of Environment, Transport, and the Regions and Department of Health, London, UK: DETR, 1998.

48. Garner JS, Hospital Infection Control Practices Advisory Committee. Guideline for isolation precautions in hospitals. Infect Control Hosp Epidemiol 1996;17:53-80.

49. Bruce BB, Blass MA, Blumberg HM, Lennox JL, del Rio C, Horsburg CR. Risk of Cryptosporidium parvum transmission between hospital roommates. Clin Infect Dis 2000;31:947-950.

50. Altekruse SF, Cohen ML, Swerdlow DL. Emerging foodborne diseases. Emerg Infect Dis 1997;3:285-293.

51. Slutsker L, Altekruse SF, Swerdlow DL. Foodborne diseases: emerging pathogens and trends. Infect Dis Clin North Am 1998;12:199-216.

52. Swerdlow DL, Altekruse SF. Food-borne diseases in the global village: what's on the plate for the 21st century. In: Scheld WM, Craig WA, Hughes JM, eds. Emerging Infections 2. Washington, DC: ASM Press; 1998:273-294.

53. Mead PS, Slutsker L, Dietz V, McCaig LF, Bresee JS, Shapiro C, et al. Food-related illness and death in the United States. Emerg Infect Dis 1999;5:607-625.

54. Armstrong GL, Hollingsworth J, Morris JG Jr. Emerging foodborne pathogens: Escherichia coli $0157: \mathrm{H} 7$ as a model of entry of a new pathogen into the food supply of the developed world. Epidemiol Rev 1996;18:29-51.

55. Park S, Worobo RW, Durst RA. Escherichia coli O157:H7 as an emerging foodborne pathogen: a literature review. Crit Rev Food Sci Nutr 1999;39:481-502.

56. Riley LW, Remis RS, Helgerson SD, McGee HB, Wells JG, Davis BR, et al. Hemorrhagic colitis associated with a rare Escherichia coli serotype. N Engl J Med 1983;308:681-685.

57. Barrett TJ, Lior H, Green JH, Khakhria R, Wells JG, Bell BP, et al. Laboratory investigation of a multistate food-borne outbreak of Escherichia coli $\mathrm{O} 157: \mathrm{H7}$ by using pulsed-field gel electrophoresis and phage typing. J Clin Microbiol 1994;32:3013-3017.

58. Whittam TS, McGraw EA, Reid SD. Pathogenic Escherichia coli O157:H7: a model for emerging infectious diseases. In: Krause RM, ed. Emerging Infections: Biomedical Research Reports. San Diego, CA: Academic Press; 1998:163-183.

59. Sparling PH. Escherichia coli O157:H7 outbreaks in the United States, 1982-1996. JAMA 1998;213:1733.

60. Verweyen HM, Karch H, Brandis M, Zimmerhackl LB. Enterohemorrhagic Escherichia coli infections: following transmission routes. Pediatr Nephrol 1999;14:73-83.

61, Parry SM, Salmon RL. Sporadic STEC O157 infection: secondary household transmission in Wales. Emerg Infect Dis 1998;4:657-661.

62. Tuttle J, Gomez T, Doyle MP, Wells JG, Zhao T, Tauxe RV, et al. Lessons from a large outbreak of Escherichia coli 0157:H7 infections: insights into the infectious dose and method of widespread contamination of hamburger patties. Epidemiol Infect 1999;122:185-192.

63. Tilden J Jr, Young W, McNamara AM, Custer C, Boesel B, Lambert-Fair MA, et al. A new route of transmission of Escherichia coli: infection from dry fermented salami. Am J Public Health 1996;86:1142-1145.

64. Karmali MA, Arbus GS, Petric M, Patrick ML, Roscoe M, Shaw J, et al. Hospital-acquired Escherichia coli $0157: \mathrm{H7}$ associated haemolytic uraemic syndrome in a nurse. Lancet 1988;1(8584):526.

65. Kohli HS, Chaudhuri AKR, Todd WTA, Mitchell AAB, Liddell KG. A severe outbreak of E. coli $\mathrm{O} 157: \mathrm{H} 7$ in two psychogeriatric wards. $J$ Public Health Med 1994;16:11-15.

66. Preston M, Borczyk A, Davidson R. Hospital outbreak of Escherichia coli O157:H7 associated with a rare phage type-Ontario. Can Communicable Dis Rep 1997;23:33-36.

67. Cheasty T, Robertson R, Chart H, Mannion P, Syed Q, Garvey R, et al. The use of serodiagnosis in the retrospective investigation of a nursery outbreak associated with Escherichia coli 0157:H7. J Clin Pathol 1998;51:498-501.

68. Weightman NC, Kirby PJG. Nosocomial Escherichia coli 0157 infection. J Hosp Infect 2000;44:107-111.

69. Spika JS, Parsons JE, Nordenberg D, Wells JG, Gunn RA, Blake PA Hemolytic uremic syndrome and diarrhea associated with Escherichia coli O157:H7 in a day care center. J Pediatr 1986;109:287-291.

70. Belongia EA, Osterholm MT, Soler JT, Ammend DA, Braun JE, MacDonald LK. Transmission of Escherichia coli 0157:H7 infection in Minnesota child day-care facilities. JAMA 1993;269:883-888.

71. Allaby MAK, Mayon-White R. Escherichia coli O 157: outbreak in a day nursery. Comm Dis Rep CDR Review 1995;5(1)R4-6.

72. Ryan CA, Tauxe RV, Hosek GW, Wells JG, Stoesz PA, McFadden HW Jr, et al. Escherichia coli O157:H7 diarrhea in a nursing home: clinical, epidemiological, and pathological findings. J Infect Dis 1986;154:631-638.

73. Carter AO, Borczyk AA, Carlson JA, Harvey B, Hockin JC, Karmali MA, et al. A severe outbreak of Escherichia coli O157:H7-associated hemorrhagic colitis in a nursing home. N Engl J Med 1987;317:1496-1500.

74. Heuvelink AE, Bleumink B, van den Biggelaar FL, Te Giffel MC, Beumer RR, de Boer E. Occurrence and survival of verocytotoxinproducing Escherichia coli 0157 in raw cow's milk in The Netherlands. J Food Prot 1998;61:1597-1601.

75. Himathongkham S, Riemann H. Destruction of Salmonella typhimurium, Escherichia coli 0157:H7 and Listeria monocytogenes in chicken manure by drying and/or gassing with ammonia. FEMS Microbiol Lett 1999;171:179-182.

76. Beuchat LR. Survival of enterohemorrhagic Escherichia coli O157:H7 in bovine feces applied to lettuce and the effectiveness of chlorinated water as a disinfectant. J Food Prot 1999;62:845-849.

77. Taormina PJ, Beuchat LR. Comparison of chemical treatments to eliminate enterohemorrhagic Escherichia coli $0157: \mathrm{H} 7$ on alfalfa seeds. $J$ Food Prot 1999;62:318-324.

78. Taormina PJ, Beuchat LR. Behavior of enterohemorrhagic Escherichia coli $\mathrm{O} 157: \mathrm{H} 7$ on alfalfa sprouts during the sprouting process as influenced by treatments with various chemicals. J Food Prot 1999;62:850856

79. Castillo A, Lucia LM, Kemp GK, Acuff GR. Reduction of Escherichia col O157:H7 and Salmonella typhimurium on beef carcass surfaces using acidified sodium chlorite. J Food Prot 1999;62:580-584.

80. Rice EW, Clark RM, Johnson CH. Chlorine inactivation of Escherichia coli O157:H7. Emerg Infect Dis 1999:5:461-463.

81. Venkitanarayanan KS, Ezeike GO, Hung YC, Doyle MP. Inactivation of Escherichia coli $\mathrm{O} 157: \mathrm{H} 7$ and Listeria monocytogenes on plastic kitchen cutting boards by electrolyzed oxidizing water. J Food Prot 1999;62:857-860.

82. Rutala WA, Barbee SL, Aguiar NC, Sobsey MD, Weber DJ. Antimicrobial activity of home disinfectants and natural products against potential human pathogens. Infect Control Hosp Epidemiol 2000;21:33-38.

83. US Food and Drug Administration. Food Code. Recommendations of the United States Public Health Service. Springfield, VA: FDA, National Technical Information; 1995

84. Taormina PJ, Beuchat LR, Slutsker L. Infections associated with eating seed sprouts: an international concern. Emerg Infect Dis 1999:5:626-634.

85. Warren JR, Marshall B. Unidentified curved bacilli on gastric epithelium in active chronic gastritis. Lancet 1983;1:1273-1275.

86. Marshall BJ, Warren JR. Unidentified curved bacilli in the stomach of patients with gastritis and peptic ulceration. Lancet 1984;1:1311-1314.

87. Gold BD, Marty A. Helicobacter pylori. In: Horsburgh CR Jr, Nelson AM, eds. Pathology of Emerging Infections. Washington, DC: American Society for Microbiology; 1997:225-241.

88. Parsonnet J. Helicobacter pylori. Infect Dis Clin North Am 1998;12:185197

89. Kuipers EJ, Blaser MJ. Helicobacter pylori and gastroduodenal disorders. In: Scheld WM, Armstrong D, Hughes JM, ed. Emerging Infections I. Washington DC: American Society for Microbiology Press; 1998:191-206.

90. Rupnow MF, Shachter RD, Owens DK, Parsonnet J. A dynamic transmission model for predicting trends in Helicobacter pylori and associated diseases in the United States. Emerg Infect Dis 2000;6:228-237.

91. Sahay P, Axon ATR. Reservoirs of Helicobacter pylori and modes of transmission. Helicobacter 1996;1:175-182.

92. Thomas JE, Gibson GR, Darboe MK, Dale A, Weaver LT Isolation of Helicobacter pylori from human faeces. Lancet 1992;340:1194-1195.

93. Parsonnet J, Shmuely H, Haggerty T. Fecal and oral shedding of Helicobacter pylori from healthy infected adults. JAMA 1999;282:22402245.

94. Hardo PG, Tugnait A, Hassan F, Lynch DAF, West AP, Mapstone NP, et al. Helicobacter pylori infection and dental care. Gut 1995;37:44-46.

95. Begue RE, Gonzales JL, Correa-Gracian H, Tang SC. Dietary risk factors associated with the transmission of Helicobacter pylori in Lima, Peru. Am J Trop Med Hyg 1998;59:637-640.

96. Klein PD, Gastrointestinal Physiology Working Group, Graham DY, Gaillour A, Opekun AR, Smith EO. Water source as risk factor for 
Helicobacter pylori infection in Peruvian children. Lancet 1991;337:15031506.

97. Tytgat GN. Endoscopic transmission of Helicobacter pylori. Aliment Pharmacol Ther 1995;9(suppl 2):105-110.

98. Gullini S, Boccini S, Contarini D, Macario F, Basso O. Is transmission of Campylobacter pylori by endoscopic examination possible? Endoscopy 1988;20:162.

99. Ramsey EJ, Carey KV, Peterson WL, Jackson JJ, Murphy FK, Read NW, et al. Epidemic gastritis with hypochlorhydria. Gastroenterology 1979;76:1449-1457.

100. Gledhill T, Leicester RJ, Addis B, Lightfoot N, Barnard J, Viney N, et al. Epidemic hypochlorhydria. BMJ 1985;290:1383-1386.

101. Miyaji H, Kohli Y, Azuma T, Ito S, Hirai M, Ito Y, et al. Endoscopic cross-infection with Helicobacter pylori. Lancet 1995;345:464.

102. Debongnie JC, Bouckaert A. Transmission of Helicobacter pylori by endoscopy? Endoscopy 1993;25:436.

103. Wu MS, Wang JT, Yang JC, Wang HH, Sheu JC, Chen DS, et al. Effective reduction of Helicobacter pylori infection after upper gastrointestinal endoscopy by mechanical washing of the endoscope. Endoscopy 1996;43:1660-1664.

104. Langenberg W, Rauws EAJ, Oudbier JH, Tytgat GNJ. Patient-to-patienttransmission of Campylobacter pylori infection by fiberoptic gastroduodenoscopy and biopsy. J Infect Dis 1990;161:507-511.

105. van der Hulst RWM, Koycu B, Keller JJ, Feller M, Rauws EAJ, Dankert $\mathrm{J}$, et al. $H$. pylori reinfection after successful eradication analyzed by RAPD or RFLP. Gastroenterology 1996;110:A284. Abstract.

106. Figura N. Mouth-to-mouth resuscitation and Helicobacter pylori infection. Lancet 1996;347:1342

107. Chong J, Marshall BJ, Barkin JS, McCallum RW, Reiner DK, Hoffman $\mathrm{SR}$, et al. Occupational exposure to Helicobacter pylori for the endoscopy professional: a sera epidemiological study. $A m \mathrm{~J}$ Gastroenterology 1994;89:1987-1992.

108. Nabwera HM, Logan RP. Epidemiology of Helicobacter pylori: transmission, translocation and extragastric reservoirs. J Physiol Pharmacol 1999;50:711-722.

109. Cellini L, Allocati N, Angelucci D, Iezzi T, Di Campli E, Marzio L, et al. Coccoid Helicobacter pylori not culturable in vitro reverts in mice. Microbiol Immunol 1994;38:843-850.

110. West AP, Millar MR, Tompkins DS. Effect of physical environment on survival of Helicobacter pylori. J Clin Pathol 1992;45:228-231.

111. Shahamat M, Mai U, Paszko-Kolva C, Kessel M, Colwell, RR. Use of autoradiography to assess viability of Helicobacter pylori in water. Appl Environ Microbiol 1993;59:1231-1235.

112. Fan XG, Chua A, Li TG, Zeng OS. Survival of Helicobacter pylori in milk and tap water. J Gastroenterol Hepatol 1998;13:1096-1098.

113. Hulten K, Enroth H, Nystrom T, Engstrand L. Presence of Helicobacter species DNA in Swedish water. J Appl Microbiol 1998;85:282-286.

114. Sasaki K, Tajiri Y, Sata M, Fujii Y, Matsubara F, Zhao M, et al. Helicobacter pylori in the natural environment. Scand J Infect Dis 1999;31:275-279.

115. Akamatsu T, Tabata K, Hironga M, Kawakami H, Uyeda M. Transmission of Helicobacter pylori infection via flexible fiberoptic endoscopy. Am J Infect Control 1996;24:396-401.

116. Graham DY, Osato MS. Disinfection of biopsy forceps and culture of Helicobacter pylori from gastric mucosal biopsies. Am J Gastroenterol 1999;94:1422-1423.

117. Kaneko H, Mitsuma T, Kotera H, Uchida K, Furusawa A, Morise K. Are routine cleaning methods sufficient to remove Helicobacter pylori from endoscopic equipment? Endoscopy 1993;25:435

118. Fantry GT, Zheng QX. James SP. Conventional cleaning and disinfection techniques eliminate the risk of endoscopic transmission of Helicobacter pylori. Am J Gastroenterol 1995;90:227-232.

119. Cronmiller JR, Nelson DK, Jackson DK, Kim CH. Efficacy of conventional endoscopic disinfection and sterilization methods against Helicobacter pylori contamination. Helicobacter 1999;4:198-203.

120. Shimada T, Terano A, Ota S, Takikawa H, Sumino S. Risk of iatrogenic transmission of Helicobacter pylori by gastroscopes. Lancet 1996;347:1342-1343.

121. Roosendaal R, Kuipers EJ, van den Brule AJC, Pena AS, Meuwissen SGM, Walboomers JMM, et al. Detection of Helicobacter pylori DNA by PCR in gastrointestinal equipment. Lancet 1993;341:900.

122. Johnson CH, Rice EW, Reasoner DJ. Inactivation of Helicobacter pylori by chlorination. Appl Environ Microbiol 1997:63:4969-4970.

123. Centers for Disease Control and Prevention. Recommendations for prevention and control of hepatitis C (HCV) infection and HCV-related chronic disease. MMWR 1998;47(RR-19):1-39

124. Alter MJ, Kruszon-Moran D, Nainan OV, McQuillan GM, Gao F, Moyer LA, et al. The prevalence of hepatitis C virus infection in the United States, 1988 through 1994. N Engl J Med 1999;341:556-562.

125. Alter MJ. Hepatitis C infection in the United States. J Hepatol 1999;31(suppl 1):88-91.
126. Fridey JL. Hepatitis C and transfusions: "lookback" primer [CD-ROM, version 8]. Wellesley, MA: UpToDate; 2000.

127. Schreiber GB, Busch MP, Kleinman SH, Korelitz JJ. The risk of transfusion-transmitted viral infections. N Engl J Med 1996;334:1685-1690.

128. Mauser-Bunschoten EP, Bresters D, van Drimmelen AA, Roosendaal G, Cuypers HT, Reesink HW, et al. Hepatitis C infection and viremia in Dutch hemophilia patients. J Med Virol 1995;45:241-246.

129. Bjoro K, Froland SS, Yun Z, Samdal HH, Haaland T. Hepatitis C infection in patients with primary hypogammaglobulinemia after treatment with contaminated immune globulin. N Engl J Med 1994;331;1607-1611.

130. Quinti I, Pandolfi F, Paganelli R, el Salman D, Giovannetti A, Rosso R, et al. HCV infection in patients with primary defects of immunoglobulin production. Clin Exp Immunol 1995;102:11-16.

131. Bjoro K, Shaug K, Haaland T, Froland SS. Long-term outcome of chronic hepatitis $\mathrm{C}$ virus infection in primary hypogammaglobulinemia. QJM 1999;92:433-441.

132. Power JP, Lawlor E, Davidson F, Holmes EC, Yap PL, Simmonds P. Molecular epidemiology of an outbreak of infection with hepatitis $\mathrm{C}$ virus in recipients of anti-D immunoglobulin. Lancet 1995;345:1211-1213.

133. Kenny-Walsh E. Clinical outcomes after hepatitis C infection from contaminated anti-D immune globulin. N Engl J Med 1999;340:1228-1233.

134. Guyer B, Bradley DW, Bryan JA, Maynard JE. Non-A, non-B hepatitis among recipients in a plasmapheresis stimulation program. J Infect Dis 1979;139:634-640

135. Muss N, Frosner GG, Sandhofer F. Epidemic outbreak of non-A, non-B hepatitis in a plasmapheresis center, I: epidemiological observations. Infection 1985;13:57-60.

136. Eggen BM, Nordbo SA. Transmission of HCV by organ transplantation. N Engl J Med 1992;326:411.

137. Cardo DM, Bell DM. Bloodborne pathogen transmission in health care workers. Infect Dis Clin North Am 1997;11:331-346.

138. Sanchez-Tapias JM. Nosocomial transmission of hepatitis C virus. $J$ Hepatol 1999;31(suppl 1):107-112.

139. Rosen HR. Primer on hepatitis $\mathrm{C}$ for hospital epidemiologists. Infect Control Hosp Epidemiol 2000;21:229-234.

140. Beltrami EM, Williams IT, Shapiro CN, Chamberland ME. Risk and management of blood-borne infections in health care workers. Clin Microbiol Rev 2000;13:385-407.

141. Pereira BJ, Levey AS. Hepatitis C virus infection in dialysis and renal transplantation. Kidney Int 1997;51:981-999.

142. Moyer LA Alter MJ. Hepatitis C virus in the hemodialysis setting: a review with recommendations for control. Semin Dial 1994;7:124-127.

143. Wreghitt TG. Blood-borne virus infections in dialysis units-a review. Rev Med Virol 1999;9:101-109.

144. Tokars JI, Miller ER, Alter MJ, Arduino MJ. National surveillance of dialysis associated diseases in the United States, 1995. ASAIO J 1998;44:98-107.

145. Tokars JI, Miller ER, Alter MJ, Arduino MJ. National surveillance of dialysis-associated diseases in the United States, 1997. Semin Dial 2000;13:75-85.

146. Allander T, Medin C, Jacobson SH, Grillner L, Persson MAA. Hepatitis $\mathrm{C}$ transmission in a hemodialysis unit: molecular evidence for spread of virus among patients not sharing equipment. J Med Virol 1994;43:415419.

147. Le Pogam S, le Chapois D, Christen R, Dubois F, Barin F, Goudeau A Hepatitis $\mathrm{C}$ in a hemodialysis unit: molecular evidence for nosocomial transmission. J Clin Microbiol 1998;36:3040-3043.

148. Norder H, Bergstrom A, Uhnoo I, Alden J, Weiss L, Czajkowski J, et al. Confirmation of nosocomial transmission of hepatitis $\mathrm{C}$ virus by phylogenetic analysis of the NS5-B region. J Clin Microbiol 1998;36:30663069 .

149. Katsoulidou A, Paraskevis D, Kalapothaki V, Arvanitis D, Karayiannis P, Hadjiconstantiou V, et al. Molecular epidemiology of hepatitis C virus outbreak in a haemodialysis unit. Nephrol, Dialy, Transplant 1999;14:1188-1194.

150. Izopet J, Pasquier C, Sandres K, Puel J, Rostaing L. Molecular evidence for nosocomial transmission of hepatitis $\mathrm{C}$ in a French hemodialysis unit. J Med Virol 1999;58:139-144.

151. Abacioglu YH, Bacaksiz F, Bahar IH, Simmonds P. Molecular evidence of nosocomial transmission of hepatitis $\mathrm{C}$ virus in a haemodialysis unit. Eur J Clin Microbiol Infect Dis 2000;19:182-186.

152. Grethe S, Gemsa F, Monazahian M, Bohme I, Uy A, Thomssen R. Molecular epidemiology of an outbreak of HCV in a hemodialysis unit: direct sequencing of HCV-HVR1 as an appropriate tool of phylogenetic analysis. J Med Virol 2000;60:152-158.

153. Alfurayh O, Sabeel A, Al Ahdal MN, Almeshari K, Kessie G, Hamid M, et al. Hand contamination with hepatitis $\mathrm{C}$ virus in staff looking after hepatitis C-positive hemodialysis patients. Am J Nephrol 2000;20:103106.

154. Bronowicki J-P, Venard V, Botte C, Monhoven N, Gastin I, Chone L, et al. Patient-to-patient transmission of hepatitis $\mathrm{C}$ virus during 
colonoscopy. N Engl J Med 1997;337:237-240.

155. Le Pogam S, Gondeau A, Bacq Y. Nosocomial transmission of hepatitis C virus. Ann Intern Med 1999;131:794.

156. Tennenbaum R, Colardelle P, Chochon M, Maisonneuve P, Jean F, Andrieu J. [Hepatitis C after retrograde cholangiography.] Gastroenterol Clin Biol 1993;17:763-764. French.

157. Widell A, Christensson B, Wiebe T, Schalen C, Hansson HB, Allander $\mathrm{T}$, et al. Epidemiologic and molecular investigation of outbreaks of hepatitis $\mathrm{C}$ virus infection on a pediatric oncology service. Ann Intern Med 1999;130:130-134.

158. Sawayama Y, Hayashi J, Kakuda K, Furusyo N, Ariyama I, Kawakami Y, et al. Hepatitis $\mathrm{C}$ virus infection in institutionalized psychiatric patients: possible role of transmission by razor sharing. Dig Dis Sci 2000;45:351356.

159. Lesourd F, Izopet J, Mervan C, Payen JL, Sandres K, Monrozies X, et al. Transmission of hepatitis $\mathrm{KC}$ virus during the ancillary procedures for assisted conception. Hum Reprod 2000;15:1083-1085.

160. Schvarcz R, Johansson B, Nystrom B, Sonnerborg A. Nosocomial transmission of hepatitis C virus. Infection 1997:25:74-77.

161. Chant K, Kociuba K, Munro R, Crone S, Kerridge R, Quin J, et al. Investigation of possible patient-to-patient transmission of hepatitis $\mathrm{C}$ in a hospital. New South Wales Public Health Bulletin 1994;5:47-51

162. Knoblanche GK. Revision of the anaesthetic aspects of an infection control policy following reporting of hepatitis C nosocomial infection. Anaesth Intensive Care 1996;24:169-172.

163. Greene ES. Hepatitis C nosocomial infection. Anaesth Intensive Care $1997 ; 25: 86-87$

164. Knoblanche G. Infection control: A reply to Prof. E. S. Greene. Anaesth Intensive Care 1997;25:87.

165. Lloyd G, Howells J, Liddle C, Klineberg PL Barriers to hepatitis C transmission within breathing systems: efficacy of a pleated hydrophobic filter. Anaesth Intensive Care 1997;25:235-238.

166. Cooper BW, Krusell A, Tilton RC, Goodwin R, Levitz RE. Seroprevalence of antibodies to hepatitis $\mathrm{C}$ virus in high-risk personnel. Infect Control Hosp Epidemiol 1992;13:82-85.

167. Thomas DL, Factor SH, Kelen GC, Washington AS, Taylor E, Quinn TC. Viral hepatitis in health care personnel at the Johns Hopkins Hospital. Arch Intern Med 1993;153:1705-1712.

168. Panlilio AL, Shapiro CN, Schable CA, Mendelson MH, Montecalvo MA, Kunches LM, et al. Serosurvey of human immunodeficiency virus, hepatitis $\mathrm{B}$ virus, and hepatitis $\mathrm{C}$ virus infection among hospital-based surgeons. Serosurvey Study Group. J Am Coll Surg $1995 ; 180: 16-24$.
169. Shapiro CN, Tokars JI, Chamberland ME. Use of the hepatitis-B vaccine and infection with hepatitis $\mathrm{B}$ and $\mathrm{C}$ among orthopaedic surgeons. The American Academy of Orthopaedic Surgeons Serosurvey Study Committee. J Bone Joint Surg Am 1996;78:1791-1800.

170. Thomas DL, Gruninger SE, Siew C, Joy ED, Quinn TC. Occupational risk of hepatitis $\mathrm{C}$ infections among general dentists and oral surgeons in North America. Am J Med 1996;100:41-45.

171. Mitsui T, Iwano K, Masuko K, Yamazaki C, Okamoto H, Tsuda F, et al. Hepatitis C infection in medical personnel after needlestick injury. Hepatology 1992;16:1109-1114.

172. Satori M, La Terra G, Aglietta M, Manzin A, Navino C, Verzetti G. Transmission of hepatitis C via blood splash into conjunctiva. Scand J Infect Dis 1993;25:270-271.

173. Ippolito G, Puro V, Petrosillo N, De Carli G, Micheloni G, Magliano E. Simultaneous infection with HIV and hepatitis C virus following occupational conjunctival blood exposure. JAMA 1998;280:28-29.

174. Hepatitis C virus transmission from health care worker to patient. Commun Dis Rep CDR Weekly 1995;5:121.

175. Esteban JI, Gomez J, Martell M, Cabot B, Quer J, Camps J, et al Transmission of hepatitis $\mathrm{C}$ virus by a cardiac surgeon. $N$ Engl J Med 1996;334:555-560

176. Transmission of hepatitis $\mathrm{C}$ virus from surgeon to patient prompts lookback. Commun Dis Rep CDR Weekly 1999:9:387.

177. Bond WW, Favero MS, Petersen NJ, Gravelle CR, Ebert JW, Maynard $\mathrm{JE}$. Survival of hepatitis B virus after drying and storage for one week. Lancet 1981;1:550-551.

178. Cuypers HT, Bresters D, Winkel IN, Reesink HW, Weiner AJ, Houghton M, et al. Storage conditions of blood samples and primer selection affect the yield of cDNA polymerase chain reaction products of hepatitis C virus. J Clin Microbiol 1992;30:3220-3224.

179. Sartor C, Charrel RN, de Lamballerie X, Sambuc R, de Micco P, Boubli $\mathrm{L}$. Evaluation of a disinfection procedure for hysteroscopes contaminated by hepatitis C virus. Infect Control Hosp Epidemiol 1999;20:434436.

180. Rey JF, Halfon P, Feryn JM, Khiri H, Masseyeff MF, Ouzan D. Risk of transmission of hepatitis $\mathrm{C}$ virus by digestive endoscopy. Gastroenterol Clin Biol 1995;19:346-349.

181. Chanzy B, Duc-Bin DL, Rousset B, Morand P, Morel-Baccard C, Marchetti B, et al. Effectiveness of a manual disinfection procedure in eliminating hepatitis $C$ virus from experimentally contaminated endoscopes. Gastrointest Endoscopy 1999;50:147-151.

182. Ouzan D. [Risk of transmission of hepatitis C through endoscopy of the digestive tract.] Presse Med 1999;28:1091-1094. French. 